COSTA, CFA; MELO, PCT; GUERRA, HP; RAGASSI, CF. 2017. Soil properties and agronomic attributes of potato grown under deep tillage in succession of grass species. Horticultura Brasileira 35: 075-081. DOI - http://dx.doi.org/10.1590/S0102-053620170112

\title{
Soil properties and agronomic attributes of potato grown under deep tillage in succession of grass species
}

\author{
Cristiano FA Costa ${ }^{1}$; Paulo CT Melo ${ }^{1}$; Henrique P Guerra ${ }^{1}$; Carlos F Ragassi ${ }^{2}$
}

${ }^{1}$ Escola Superior de Agricultura Luiz de Queiroz (ESALQ), Piracicaba-SP, Brasil; cristianofacosta@hotmail.com; paulomelo@usp.br; henriquepose@gmail.com; ${ }^{2}$ Embrapa Hortaliças, Brasília-DF, Brasil; carlos.ragassi@embrapa.br

\begin{abstract}
Yield and disease incidence were evaluated in potato (Solanum tuberosum, cv. Atlantic) after six years of cultivation in succession with corn (Zea mays, cv. 'AG 6080') under conventional tillage (CT, depth of tillage: $20 \mathrm{~cm}$ ) or in succession with three grass species [Guinea grass (Panicum maximum, cv. Tanzânia), Palisade grass (Brachiaria brizantha, cv. Marandu) and corn] under deep tillage (DT, depth of tillage: $70 \mathrm{~cm}$ ). Total tuber yield was higher in DT in average $36 \%$ the value obtained in CT $(17.76 \mathrm{t} / \mathrm{ha})$, with no effect of the grass species. Common scab (Streptomyces scabies) incidence was influenced by treatments, the highest (16.9\%) and the lowest $(9.5 \%)$ values being obtained in succession with corn and Guinea grass, respectively, both under DT. The lowest incidence of tuber greening at field $(2.58 \%)$ was also recorded in Guinea DT, significantly lower than obtained in Corn CT (6.33\%), possibly due to a more efficient ridging operation. Grass species showed different values of aboveground dry biomass production. Guinea grass $(26.56 \mathrm{t} / \mathrm{ha})$ was the most and Corn under CT and DT (5.72 and $5.56 \mathrm{t} / \mathrm{ha}$, respectively, without ears) were the least productive ones. Soil density, macroporosity and resistance to penetration indices were significantly better with DT, the grass species affecting them in a minor degree. The deep tillage system is, therefore, recommended for potato cultivation regardless the grass species used for crop succession.
\end{abstract}

Keywords: Solanum tuberosum, compaction, soil recuperation, crop succession.

\section{RESUMO}

Atributos do solo e da cultura da batata em preparo profundo de solo e sucessão com poáceas

A produtividade e a incidência de doenças foram avaliadas na cultura da batata (Solanum tuberosum, cv. Atlantic) após seis anos de cultivo em sucessão com milho (Zea mays, cv. 'AG 6080') sob manejo de solo convencional (CT, profundidade da operação de preparo: $20 \mathrm{~cm}$ ) ou em sucessão de culturas com três espécies de poácea [capim Tanzânia (Panicum maximum, cv. Tanzânia), capim Marandu (Brachiaria brizantha, cv. Marandu) e milho], sob manejo profundo de solo (DT, profundidade da operação de preparo: $70 \mathrm{~cm}$ ). A produtividade total em tubérculos para os tratamentos em DT foi, em média, 36\% maior em relação ao CT (17,76 t/ha), não havendo efeito da poácea cultivada em sucessão. A incidência de sarna comum (Streptomyces scabies) foi influenciada pelos tratamentos, sendo a mais alta $(16,9 \%)$ e a mais baixa $(9.5 \%)$ registradas quando milho e capim Tanzânia, respectivamente, foram utilizados como cultura em sucessão, ambos sob DT. A incidência mais baixa de esverdeamento de tubérculos em campo (2,58\%) foi também obtida para sucessão com capim Tanzânia sob DT, significativamente inferior ao valor obtido em milho $\mathrm{CT}(6,33 \%)$, possivelmente devido à maior eficácia da operação de amontoa. As diferentes poáceas apresentaram valores diferentes de produção de biomassa seca de parte aérea. O capim Tanzânia (26,56 t/ha) foi a poácea mais produtiva e o milho sob CT e DT (5,72 e 5,56 t/ha, respectivamente, sem considerar as espigas) foi a menos produtiva. Densidade e macroporosidade, assim como o índice de resistência à penetração do solo foram significativamente mais favoráveis nos tratamentos com DT e a espécie de poácea cultivada em sucessão os afetou em menor grau. O manejo profundo do solo é, portanto, recomendado para o cultivo da batata independentemente da espécie de poácea utilizada como cultura em sucessão.

Palavras-chave: Solanum tuberosum, compactação, recuperação do solo, sucessão de culturas.

Received on October 16, 2015; accepted on July 22, 2016

$\mathrm{P}$ otato production in Brazil stands out for socio-economic importance. In 2004-2013, the harvested area decreased by $11.1 \%$, while potato production and productivity increased by $17.1 \%$ and $30.1 \%$, respectively. In 2013, Brazilian production reached 3.57 million tons, the harvested area summed 128.43 thousand ha and the average yield was
$27.80 \mathrm{t} / \mathrm{ha}$ (IBGE, 2014).

Since 1920, when potato crop began to be cultivated on a commercial scale in the Country, plowing in total area is used, favoring the formation of a compacted layer below the plowed region $(20 \mathrm{~cm})$ due to destruction of soil structure and subsequent vertical movement of clay, which is deposited in the subsurface (Thornton et al., 2008). Even nowadays, implements with a shallow action $(0-20 \mathrm{~cm})$, such as disc harrow and/or plow are widely used in the potato production systems (Jadoski et al., 2012).

The subsoil compaction directly affects potato root growth due to mechanical resistance to penetration 
(Stalham et al., 2007). A shallow root system limits the ability of the plant to uptake nutrients as well as the resistance to periods of water stress. Consequently, plants become less vigorous and quality and yield of tubers are reduced (Thornton et al., 2008). Other indirect losses as consequence of compaction can also occur to the potato crop, such as those related to poor drainage, generating favorable environment to the incidence of diseases by waterlogging. In this sense, a number of reports associating root rot with soil compaction are found in scientific literature (Ragassi et al., 2011).

A system based on deep cultivation is proposed, therefore. This technique, named 'deep tillage' or 'DT' herein, was developed aiming to provide physical and biological conditions of soil for adequate potato growing. DT has been evaluated for six years in a long-term experiment, benefits having been reported from the first two years of evaluation (Ragassi et al., 2009).

DT consists in the use of implements with deep action into the soil, reaching up to $70 \mathrm{~cm}$ depth to lighten deep compaction, zero traffic (Young et al., 1993), precision tillage (Bishop \& Grimes, 1978) and succession with grass species in order to input large amounts of organic matter to the soil for activation of beneficial biological processes (Abreu et al., 2004), such as the formation of soil aggregates (Vezzani et al., 2008), which contributes to reduce compaction (Bronick \& Lal, 2005). Hypothetically, DT would provide a more favorable condition to the potato crop production, with an increase of yield and a lower incidence of diseases on tubers. These effects would depend on the grass species cultivated previously to potato.

The objective of the present research was to compare the effect of two tillage systems, 'conventional tillage' (CT) associated with the cultivation of corn (Zea mays hybrid 'AG 6080') and 'deep tillage' (DT) associated with the cultivation of corn, Guinea grass (Panicum maximum, cv. Tanzania) or Palisade grass (Brachiaria brizantha, cv. Marandu) on the soil traits, occurrence of diseases and yield of potato (Solanum tuberosum, cv. Atlantic).

\section{MATERIAL AND METHODS}

The experiments were part of a long-term field research initiated in 2006 (Ragassi, 2009) on a Rhodic Nitisol, in Piracicaba, São Paulo State, Brazil (22 ${ }^{\circ} 42^{\prime} \mathrm{S}, 4^{\circ} 38^{\prime} \mathrm{W}, 569 \mathrm{~m}$ elevation). Results reported herein were obtained from the sixth cycle of the crop succession grass species - potato (20112012). For potato yield, results obtained from the previous cycle (2010-2011) are also presented. Four succession models were the treatments $\mathrm{T} 1$ : succession Guinea grass (Panicum maximum, cv. Tanzânia) - potato (Solanum tuberosum, cv. Atlantic), under deep tillage (Guinea DT), T2: succession Palisade grass (Brachiaria brizantha, cv. Marandu) - potato, under deep tillage (Palisade DT) and T3: succession corn (Zea mays, cv. 'AG 6080') - potato, under deep tillage (Corn DT). As a control treatment (T4), succession corn - potato under the conventional tillage system (Corn $\mathrm{CT}$ ) was carried out, using only harrow up to $20 \mathrm{~cm}$ depth and bed formation before potato planting. Experimental useful plot comprised a double line (7.00 m length and $1.24 \mathrm{~m}$ width), and borders corresponded to $1.5 \mathrm{~m}$ at each line end and one double line at each plot side. Complete-randomized block was the experimental design with four treatments and six replications.

Soil tillage operations and sowing of grasses $\left(1^{\text {st }}\right.$ stage $)$ for succession with potato were carried out in October 2011. First, a shallow $(20 \mathrm{~cm})$ seedbed tiller operation was carried out using the implement model Rotin (Mafes Inteligência Agronômica). In the control treatment, field was harrowed $(20 \mathrm{~cm}$ depth) after the seedbed tiller operation. For the deep tillage treatments, a subsoiling operation was carried out using the 0.80 -meter subsoiler model Dreno (Mafes Inteligência Agronômica) in the seedbed center $(1.80 \mathrm{~m}$ width, equivalent to the tractor gauge), up to $70 \mathrm{~cm}$ depth. Then, an operation of a low-speed seedbed tiller model Turbo (Mafes Inteligência Agronômica) up to $40 \mathrm{~cm}$ depth was carried out mixing the grass biomass to the soil. Following tillage operations, broadcast sowing of grasses was carried out using $5.0 \mathrm{~kg} / \mathrm{ha}$ pure and viable seeds of Guinea grass (P. maximum, cv. Tanzânia) and Palisade grass (B. brizantha, cv. Marandu). A population of 65,000 plants per hectare was established for corn, with spacing of $60 \mathrm{~cm}$ between rows and $25 \mathrm{~cm}$ between plants. Fertilization was carried out with $150 \mathrm{~kg} / \mathrm{ha} \mathrm{N}$ and $150 \mathrm{~kg} / \mathrm{ha}$ $\mathrm{P}_{2} \mathrm{O}_{5}$ only for corn, in order to replace the main nutrients exported by grains, considering yield of $6 \mathrm{t} / \mathrm{ha}$ (Chantigny et al., 2008).

On April 2012, aboveground biomass of grasses, including corn without ears, was sampled in $1.0 \mathrm{~m}^{2}$ of each plot prior to the chopping operation. The biomass collected was weighed and a sample of about $100 \mathrm{~g}$ was collected and dried at $65^{\circ} \mathrm{C}$ for 24 hours for determining water content. Results were converted into dry biomass production per area (t/ha). Then, grass biomass (corn plants without ears) was chopped using a rotary cutting machine model Tribar (Mafes Inteligência Agronômica, Brazil), the biomass remaining on the soil until it presented a dry aspect (30 days). After drying, a chopping and a shallow rotary hoe operation were carried out again eradicating new grass shoots and first incorporating the dry biomass. These operations avoided using chemical desiccation by herbicides.

Then, in the deep tillage treatments, the 0.80 -meter subsoiler and the lowspeed rotary hoe operations were carried out over again. Mechanized planting was carried out using a potato planter machine model Ecoplan (Mafes Inteligência Agronômica) at the end of May 2012. Whole tubers 4 to $5 \mathrm{~cm}$ in diameter from the $3^{\text {rd }}$ clonal generation, cv. Atlantic, were mechanically planted. Plant spacing was $80 \mathrm{~cm}$ among rows within a double-line bed and $1.0 \mathrm{~m}$ between two beds, both for deep and conventional tillage. Plants in a row spaced $32 \mathrm{~cm}$ for all treatments resulted in a population of 38,986 plants/ha. For potato, 45, 200, 100, 5 and $10 \mathrm{~kg} / \mathrm{ha} \mathrm{N}$, $\mathrm{P}_{2} \mathrm{O}_{5}, \mathrm{~K}_{2} \mathrm{O}$, B and $\mathrm{Zn}$ were applied at planting, respectively (Raij et al., 1997).

After emergence, hilling was carried out with the equipment model Gaia (Mafes Inteligência Agronômica). 
Soil chemical analyses were carried out before grass cultivation, according to Embrapa (1997), revealing attributes presented in Table 1.

Soil penetration resistance was evaluated through the methodology described in Stolf et al. (1983) using a penetrometer model IAA/Planalsucar Stolf (KAMAQ, Brazil). Through the software 'Impact Penetrometer Stolf Model', version 2.00, values of penetration resistance were obtained in $\mathrm{MPa}$ each $20 \mathrm{~cm}$. To avoid errors from differences on soil moisture, the whole evaluation was carried out on one day, at potato 107 DAP. Data were collected at the bed center between the double lines up to $60 \mathrm{~cm}$ depth.

Intact soil samples were obtained from the soil at $15-20$ and $35-40 \mathrm{~cm}$ depth in the center of the double line at 106 DAP for determination of density and macroporosity. We used a stainless steel cylinder with $3 \mathrm{~cm}$ diameter and 5 $\mathrm{cm}$ height. Samples were placed in trays to which water was added slowly over three days up to near the sample top, without exceeding it. After saturation, samples presented a superficial water layer, their mass was determined and then they were submitted to tension equivalent to a 0.60 -meter water column until the hydrostatic equilibrium was reached (Ribeiro et al., 2007). Samples were weighed again and dried at $105^{\circ} \mathrm{C}$ for 48 hours for dry mass determination.

Macroporosity was calculated considering water specific gravity equivalent to $1 \mathrm{~g} / \mathrm{cm}^{3}$. Difference between mass of saturated sample and mass of sample under a 0.60 -meter water tension was divided by the total volume of the sample, obtaining the non-dimensional ratio volume of macropores per total volume of soil. Soil bulk density $\left(\mathrm{g} / \mathrm{cm}^{3}\right)$ was calculated by dividing the sample dry mass per total sample volume.

Number of plants with symptoms of late blight (Phytophthora infestans), blackleg (Pectobacterium spp.) and viruses (visual aspect) were determined at 29 days after planting (DAP). Disease incidence was calculated based on the ratio between the number of plants with symptoms and the total of plants per plot. For late blight, even a plant presenting low severity was considered

Tubers were classified after harvest according to size into classes: large (diameter higher than $10 \mathrm{~cm}$ ), medium (diameter between 4 and $10 \mathrm{~cm}$ ) and small (diameter lower than $4 \mathrm{~cm}$ ). After classification, fresh mass of each diameter class was determined for each plot. Fifty tubers per plot were sampled for evaluation of diseases, pests and physiological damages.

Data were analyzed (ANOVA, $\mathrm{p} \leq 0.05$ ) and means were compared by Tukey, 5\%. For soil penetration resistance, analyses were done following the split-plot scheme, treatments corresponding to the main plots and depth (0.20-meter layer) corresponding to the sub-plots. Similarly, macroporosity and soil density were analyzed as a splitplot, layers $(15-20$ and $35-40 \mathrm{~cm})$ being considered as the sub-plots.

To meet ANOVA requirements, some variables were transformed: i) grass-species aboveground dry biomass production and ii) soil penetration resistance into $\log _{10}(\mathrm{x})$. Data presented were converted back to the original scale after analysis to facilitate comprehension. Assistat software (Silva et al., 2002) was used for all statistical analyses carried out.

\section{RESULTS AND DISCUSSION}

Grass species presented different as positive.

$(p<0.01)$ aboveground dry biomass production, in the following descending order: Guinea Deep Tillage (DT) $>$ Palisade DT $>$ Corn DT $=$ Corn Conventional Tillage (CT) (Table 2). All considering 150 days of cultivation. The mass production (excluding ears) of corn was the lowest among species studied, without differing between the tillage systems. Absence of hydric limitation throughout the evaluation period must be considered. Rain during months when grass species were cultivated was quite abundant, namely October 2011 (193.9 mm), November 2011 (155.3 $\mathrm{mm})$, December 2011 (153.4 mm), January 2012 (214.9 mm), February 2012 (138.7 mm), March 2012 (61.5 $\mathrm{mm})$ and April 2012 (159.2 mm). Hypothetically, the deep tillage could have provided deep soil exploitation by roots, which would be an advantage to the corn crop under water limitation. This advantage, however, could not be noticed under the conditions prevailing during the experimental period. In the second year of evaluation (Ragassi, 2009), Guinea grass also stood out with the highest numerical value of dry matter yield (13.6 t/ha), however, statistically different in comparison to Corn CT (8.9 t/ha), only. Guinea grass, among the grass species studied, presented the highest productivity under evaluated conditions, this being the most interesting crop for succession with the potato crop when considering only the trait aboveground biomass production.

Soil penetration resistance was evaluated in the bed center,

Table 1. Chemical attributes of a Rhodic Nitisol used for evaluating a deep soil tillage system in association with crop succession for potato. Piracicaba, ESALQ, 2013.

\begin{tabular}{|c|c|c|c|c|c|c|c|}
\hline \multirow{2}{*}{$\begin{array}{l}\text { Depth } \\
\text { (cm) }\end{array}$} & \multirow{2}{*}{$\begin{array}{c}\mathrm{pH} \\
\left(\mathrm{CaCl}_{2}\right)\end{array}$} & \multirow{2}{*}{$\begin{array}{l}\text { O.M. } \\
\left(\mathrm{g} / \mathrm{dm}^{3}\right)\end{array}$} & $\mathbf{P}_{\text {resin }}$ & $\mathrm{Cu}$ & $\mathrm{Fe}$ & $\mathbf{Z n}$ & Mn \\
\hline & & & \multicolumn{5}{|c|}{$\left(\mathrm{mg} / \mathrm{dm}^{3}\right)$} \\
\hline $0-20$ & 5.5 & 19.0 & 52.0 & 6.6 & 30 & 8.3 & 27.6 \\
\hline $20-40$ & 5.8 & 14.0 & 20.0 & 4.9 & 29 & 2.0 & 24.4 \\
\hline \multirow[t]{3}{*}{$40-80$} & 5.8 & 8.5 & 9.5 & 2.4 & 11 & 0.9 & 8.0 \\
\hline & $\mathbf{K}$ & $\mathrm{Ca}$ & Mg & Al & CEC $^{1}$ & ${\mathrm{~S}-\mathrm{SO}_{4}}_{4}$ & B \\
\hline & \multicolumn{6}{|c|}{$\left(\mathrm{mmol}_{\mathrm{c}} / \mathrm{dm}^{3}\right)$} & $\left(\mathrm{mg} / \mathrm{dm}^{3}\right)$ \\
\hline $0-20$ & 4.5 & 53 & 16.0 & 0 & 108 & 11 & 0.40 \\
\hline $20-40$ & 3.5 & 51 & 18.5 & 0 & 107 & 33 & 0.39 \\
\hline $40-80$ & 2.0 & 47 & 17.0 & 0 & 91 & 67 & 0.39 \\
\hline
\end{tabular}

${ }^{1}$ Cation Exchange Capacity 
corresponding to the subsoiled region in DT, and the analyses considering a split-plot design revealed a significant effect of treatments, depth as well as of the interaction between them (Table 3). Values increased with depth and were generally higher in CT. Detailing the interaction allowed noticing penetration resistance in CT increased with depth, whereas DT showed significant differences among the most superficial layer $(0-20 \mathrm{~cm})$ and the other ones, only. These results confirmed the trends observed in the second year of assessment (Ragassi et $a l ., 2009)$ at depths of $0-20 \mathrm{~cm}$ and 40 $60 \mathrm{~cm}$. Some differences were observed, however. Considering $20-40 \mathrm{~cm}$ at that first evaluation in the second year of crop succession, significant difference was found between Guinea DT and Corn CT, only, the other DT treatments remaining in an intermediate position. Conventional tillage, in the current assessment, presented penetration resistance significantly higher than all treatments when considering all evaluations below $20 \mathrm{~cm}$. The most superficial layer evaluated $(0-20 \mathrm{~cm})$ showed no difference for any of the comparisons between treatments, confirming the efficacy of $\mathrm{CT}$ for this depth.

When considering $1.5 \mathrm{MPa}$ as a reference (Stalham et al., 2007), no limitation for the potato root growth occurred up to $20 \mathrm{~cm}$ depth for all treatments. Nevertheless, only DT treatments presented no limiting penetration resistance at $20-40 \mathrm{~cm}$. Conventional tillage had a penetration resistance value at $40-60 \mathrm{~cm} 70 \%$ to $89 \%$ higher in comparison to the DT treatments. However, all treatments showed some degree of restriction to root growth in this depth. Conventional tillage, thus, provided limitation for root growth from the $20-40 \mathrm{~cm}$ layer on, a lower depth in comparison to the deep tillage system.

In a series of experiments in England, soil compaction was found to delay emergence, reduce leaf-area expansion-rate, light interception and the potato cycle duration. These factors combined have impaired tuber yield (Stalham et al., 2007). In that research, density of roots and the depth achieved by them were significantly reduced by compaction, especially in areas wherein compaction occurred in more superficial layers $($ e.g. $10 \mathrm{~cm}$ ) rather than in deeper ones (e.g. $40 \mathrm{~cm}$ ) (Stalham et al., 2007). Thus, as long as DT provides no limitation for root growth (i.e. penetration resistance lower than 1.5 MPa) up to $20-40 \mathrm{~cm}$, the potential of this tillage in promoting potato root growth by reducing compaction is confirmed.

Macroporosity was affected significantly by treatments, as well as by the depth of evaluation (Table 4). The interaction between these two factors was also significant, so details are presented.

Reduction of macroporosity with increasing depth was expected, but this reduction only occurred in CT. For Corn DT and Guinea DT, no significant difference between the layers was observed and for Palisade DT, macroporosity at $35-40 \mathrm{~cm}$ was $25 \%$ higher than obtained in $15-20 \mathrm{~cm}$. When comparing the treatments at the more superficial layer, Corn DT presented a macroporosity $36 \%$ higher than Corn CT while the other treatments showed intermediate values. At the higher depth, differences were even more evident, Palisade DT presenting a macroporosity 94\% higher than Corn CT and 20\% higher than Corn DT.

For bulk density, the treatment effect was significant, but not the effect of depth and depth $\mathrm{x}$ treatment interaction (Table 4). Conventional tillage presented a bulk density value higher than the DT treatments, which were not different among them. The deep tillage, thus, provided a lower soil bulk density, regardless the grass species used or depth evaluated.

Deep tillage was expected to provide a higher level of macroporosity, especially

Table 2. Potato yield (two crop cycles) and biomass produced by grass species (one crop cycle) cultivated in succession to potato, under deep and conventional tillage. Piracicaba, ESALQ, 2013.

\begin{tabular}{lccc}
\hline Treatment $^{1}$ & \multicolumn{2}{c}{ Potato yield (t/ha) (2011-2012) } & Grass biomass $^{\mathbf{2}(2012)}$ \\
\hline Corn CT & $18.64 \mathrm{~b}$ & $17.75 \mathrm{~b}$ & $5.72 \mathrm{c}$ \\
Guinea DT & $24.19 \mathrm{a}$ & $23.25 \mathrm{a}$ & $26.56 \mathrm{a}$ \\
Palisade DT & $21.32 \mathrm{ab}$ & $25.02 \mathrm{a}$ & $17.94 \mathrm{~b}$ \\
Corn DT & $22.90 \mathrm{a}$ & $24.08 \mathrm{a}$ & $5.56 \mathrm{c}$ \\
\hline CV $(\%)$ & $10.76^{*}$ & $13.91^{*}$ & $1.15^{* *}$ \\
\hline
\end{tabular}

${ }^{1} \mathrm{CT}=$ conventional tillage; $\mathrm{DT}=$ deep tillage; Guinea $=$ Guinea grass; Palisade $=$ Palisade grass; ${ }^{2}$ Grass biomass corresponds to the aboveground part dry biomass of the grass species; **** significant, 5 and $1 \%$, respectively; Means followed by different letters in the column are significantly different, Tukey, $5 \%$.

Table 3. Soil penetration resistance $(\mathrm{MPa})$ at 107 days after potato planting depending on treatments and depth. Piracicaba, ESALQ, 2013.

\begin{tabular}{lccc}
\hline Treatment $^{1}$ & \multicolumn{3}{c}{ Depth (cm) } \\
\cline { 2 - 4 } & $\mathbf{( 0 - 2 0 )}$ & $\mathbf{( 2 0 - 4 0 )}$ & $\mathbf{( 4 0 - 6 0 )}$ \\
\hline Corn CT & $0.81 \mathrm{aC}$ & $1.80 \mathrm{aB}$ & $2.91 \mathrm{aA}$ \\
Guinea DT & $0.77 \mathrm{aB}$ & $1.23 \mathrm{bA}$ & $1.54 \mathrm{bA}$ \\
Palisade DT & $0.78 \mathrm{aB}$ & $1.28 \mathrm{bA}$ & $1.68 \mathrm{bA}$ \\
Corn DT & $0.84 \mathrm{aB}$ & $1.32 \mathrm{bA}$ & $1.71 \mathrm{bA}$ \\
\hline
\end{tabular}

$\mathrm{CV}^{2}(\%) 2.25^{* *}$

$\mathrm{CV}^{3}(\%) 2.70^{*}$

${ }^{1} \mathrm{CT}=$ conventional tillage; $\mathrm{DT}=$ deep tillage Guinea $=$ Guinea grass $;$ Palisade $=$ Palisade grass; ${ }^{2}$ Coefficient of variation for comparison between depths; ${ }^{3}$ among treatments. **** significant, 5 and $1 \%$, respectively; Means followed by different lowercase letters are different among treatments (column) and uppercase letters among depths (line). 
Table 4. Macroporosity and density of soil evaluated at 106 days after potato planting, depending on soil tillage and grass species cultivated as succession crop. Piracicaba, ESALQ, 2013.

\begin{tabular}{|c|c|c|c|c|}
\hline \multirow{3}{*}{ Treatment $^{1}$} & \multicolumn{2}{|c|}{ Macroporosity $^{2}(\%, v / v)$} & \multicolumn{2}{|c|}{$\operatorname{Density}^{3}\left(\mathrm{~g} / \mathrm{dm}^{3}\right)$} \\
\hline & \multicolumn{4}{|c|}{ depth (m) } \\
\hline & $0.15-0.20$ & $0.35-0.40$ & $0.15-0.20$ & $0.35-0.40$ \\
\hline Corn CT & $13.1 \mathrm{bA}$ & $10.1 \mathrm{cB}$ & $1.38 \mathrm{a}$ & $1.45 \mathrm{a}$ \\
\hline Guinea DT & $16.2 \mathrm{abA}$ & $17.8 \mathrm{abA}$ & $1.24 \mathrm{~b}$ & $1.18 \mathrm{~b}$ \\
\hline Palisade DT & $15.6 \mathrm{abB}$ & $19.6 \mathrm{aA}$ & $1.25 \mathrm{~b}$ & $1.16 \mathrm{~b}$ \\
\hline \multirow[t]{3}{*}{ Corn DT } & $17.9 \mathrm{aA}$ & $16.4 \mathrm{bA}$ & $1.27 \mathrm{~b}$ & $1.19 \mathrm{~b}$ \\
\hline & \multicolumn{2}{|c|}{$\mathrm{CV}^{4}(\%) 14.11^{* *}$} & \multicolumn{2}{|c|}{$\mathrm{CV}^{6}(\%) 2.54^{* *}$} \\
\hline & \multicolumn{2}{|c|}{$\mathrm{CV}^{5}(\%) 12.25^{* *}$} & \multicolumn{2}{|c|}{$\mathrm{CV}^{7}(\%) 6.70^{* *}$} \\
\hline
\end{tabular}

${ }^{1} \mathrm{CT}=$ conventional tillage; DT $=$ deep tillage; Guinea $=$ Guinea grass; Palisade $=$ Palisade grass; ${ }^{2}$ Lowercase letters correspond to comparison among treatments (column) and uppercase letters among depths (line); ${ }^{3}$ Different letters correspond to significant differences among treatments, Tukey, $5 \% ;{ }^{4 ; 6}$ Coefficient of variation for comparison between depths; and ${ }^{5 ; 7}$ among treatments. ${ }^{* *}$ Significant at $1 \%$.

Table 5. Incidence of damages on potato tubers depending on the tillage system and the grass species cultivated as succession crop. Piracicaba, ESALQ, 2013.

\begin{tabular}{|c|c|c|}
\hline \multirow{2}{*}{ Treatment $^{1}$} & Common scab & Greening \\
\hline & \multicolumn{2}{|c|}{ Tubers affected (\%) } \\
\hline Corn CT & $15.66 \mathrm{ab}$ & $6.33 \mathrm{a}$ \\
\hline Guinea DT & $9.50 \mathrm{c}$ & $2.58 \mathrm{~b}$ \\
\hline Palisade DT & $11.66 \mathrm{bc}$ & $3.22 \mathrm{ab}$ \\
\hline Corn DT & $16.90 \mathrm{a}$ & $4.10 \mathrm{ab}$ \\
\hline CV $(\%)$ & $20.78^{* *}$ & $38.11^{*}$ \\
\hline
\end{tabular}

${ }^{1} \mathrm{CT}=$ conventional tillage; $\mathrm{DT}=$ deep tillage; Guinea = Guinea grass; Palisade = Palisade grass; *Significant at $5 \%$; * significant at $1 \%$; Means followed by different letters are significantly different, Tukey $5 \%$.

below $20 \mathrm{~cm}$, which was confirmed by the analysis. However, the effect of DT was also noticed in the superficial layer $(15-20 \mathrm{~cm})$, demonstrating a higher efficacy of this system even on this shallower layer. Among DT treatments, grass species with a higher biomass production were expected to provide a higher macroporosity, which was fairly confirmed especially at $35-40 \mathrm{~cm}$, corn DT (5.56 t/ha aboveground dry biomass production) presenting a lower macroporosity level in comparison to the other DT treatments. The higher biomass produced by Guinea grass (26.56 t/ha), however, did not represent an increase in macroporosity when comparing to Palisade grass (17.94 t/ha). Possibly, Palisade grass has attributes which may favor macroporosity at $35-40 \mathrm{~cm}$. Root biomass production is a factor, which was not considered in our current evaluations, but may have affected macroporosity.

A previous analysis corresponding to the second year of evaluation revealed a root dry biomass production of 0.3 $\mathrm{mg} / \mathrm{dm}^{3}$ soil for Palisade grass at $40-60$ $\mathrm{cm}$ depth, equivalent to four times the value for Guinea grass at the same depth range (Ragassi, 2009). A number of researches, such as Salton et al. (2008), demonstrate the influence of roots on soil structure and, therefore, this factor may have influenced the macroporosity value of Palisade DT at $35-40 \mathrm{~cm}$.

Studies have established a minimum macroporosity level of $10 \%(\mathrm{v} / \mathrm{v})$ required for plant growth (Silva et $a l ., 2004)$. Considering this value as a reference, no restriction occurred for any treatment at the two depths evaluated in our research.

Another study, on the same soil type of the present research, compared density and macroporosity at $0-5 \mathrm{~cm}$ among areas under native vegetation, soil under conventional tillage (disk harrow and leveling harrow) and a production field under no-till for 4, 5 and 12 years. The highest macroporosity recorded was $27 \%$, obtained under notill for 12 years, whereas the lowest was $17 \%$, obtained in conventional tillage and no-till for 4 years. Soil bulk density ranged from $1.05 \mathrm{~g} / \mathrm{dm}^{3}$ in native forest to $1.22 \mathrm{~g} / \mathrm{dm}^{3}$ under conventional tillage, whereas intermediate values were obtained under no-till, density of 1.06 $\mathrm{g} / \mathrm{dm}^{3}$ provided by no-till for 12 years, a value close to that determined under native vegetation (Assis \& Lanças, 2005).

In our study, macroporosity and soil density presented a lower range in comparison to the mentioned research (Assis \& Lanças, 2005). Furthermore, results obtained herein are closer to the lowest obtained for macroporosity and to the highest recorded for density by Assis \& Lanças (2005), possibly indicating that the studied soil presents some degree of degradation, even after six years of cultivation with DT. Indices of density and macroporosity, however, were significantly better with the use of DT and therefore, we conclude that DT is more effective than $\mathrm{CT}$ for promoting soil restoration. The grass species used in succession to potato influences significantly the soil properties, Palisade and Guinea grasses being promising rather than corn for improving soil quality.

Potato total yield was higher for DT, regardless the grass species used for succession in the cycle 2011-2012 (Table 2). In the previous cycle, however, Palisade DT was not significantly different from Corn CT. Yield in DTtreatments were in average $36 \%$ higher than in Corn CT in 2011-2012.

Regarding the classification of tubers in diameter classes (large, medium and small), no large tubers were obtained for any treatment. No significant differences were found among treatments for percentage of medium tubers (89.9 to 93.2\% for Corn CT and Palisade DT, respectively) and small tubers (6.8 to $10.1 \%$ for Corn CT).

The higher yield obtained with DT is certainly related to the better soil 
condition, especially in the bed center, a position with no effect of traffic. The evaluation corresponding to the second year of this study demonstrates absence of DT effects, as well as influence of the grass species on soil attributes (penetration resistance, density and macroporosity) when evaluation was carried out at the line of planting, placed adjacently to the traffic row (Ragassi, 2009). In this sense, other researches demonstrated the ability of potato roots to explore a compaction-free soil region, also located externally to the row (Young et al., 1993). In the research of Young et al. (1993), the tractor gauge was adapted to $2.80 \mathrm{~m}$ and three planting lines spaced $0.81 \mathrm{~m}$ fitted the space between wheels. Those authors found no differences in productivity between plants from the sidelines (adjacent to the traffic rows) and plants collected at the central line, which was not influenced by traffic. This fact was attributed to the exploration of the bed center by the plants from the sidelines (Young et al., 1993).

Considering productivity in two cycles (Table 2), as well as in the second year of the experiment (Ragassi et al., 2009), no difference was found among DT-treatments for any year of evaluation, although the grass species have presented different characteristics and distinct influences on soil attributes.

Differently from the results presented herein, Jadoski et al. (2012) and Saito et al. (2013) obtained a higher potato yield with tillage based on reduced soil disturbance in comparison to tillage based on a higher intervention level, as DT can be considered. The advantage of DT reported herein is certainly a consequence of a limiting level of compaction present in the studied area, as demonstrated by the soil physical analysis from the conventional tillage treatment. DT, this way, could be understood as a way of bypass the compaction-related limitations in specific affected areas rather than as a general recommendation for improving potato yield regardless the soil conditions.

The tuber diseases observed in the experiments were common scab (Streptomyces scabies) and black scurf
(Rhizoctonia solani). No difference among treatments was found for black scurf (10.7\% of harvested tubers). Nevertheless, for common scab (Table 5), a significant effect occurred, Corn DT presenting an incidence $77 \%$ higher than Guinea DT. The reason is not totally clear, but factors inherent to the crop used in succession, such as a lower aboveground biomass production, may have induced a higher hydric variation during the tuberization phase, condition typically related to the incidence of this disease in production areas (De Boer, 2008; Thornton et al., 2008). In fact, data associating common scab to organic matter are very conflicting, what indicates that the source of the organic matter and/or its decomposition status might affect differently disease onset.

We observed a low overall incidence of soil diseases for all treatments, which is an important observation at the end of the sixth cycle of succession. A considerable incidence of diseases was expected in a field cultivated with potato for more than one cycle. Added to this, the symptoms found would be quite irrelevant for industrial purposes, considering the cultivar Atlantic was adopted for this study. Also, the absence of major soil pathogens (e.g. Ralstonia solanacearum, Sclerotinia spp. and nematodes) and the use of non-infested seeds are fundamental factors that afforded the study for six years in the same area.

With regard to pests, only Cucurbit beetle (Diabrotica speciosa) caused measurable damage, but no difference among treatments was observed. Occurrence of damages caused by this pest was low (10.9\% of tubers) even though potato and corn are hosts for this insect. No insecticide was applied.

A number of physiological disorders were found in tubers, such as lenticels breakdown $(6.5 \%$ of tubers) and greening (Table 5). Lenticels breakdown is a physiological disorder caused by restriction in air supplying to the tuber, usually found in waterlogged soils in which lenticels remain permanently opened, in a visible form, making the tuber susceptible to the entry of pathogens (De Boer, 2008). Greening occurs as a consequence of tuber exposition to the sun, triggering a reaction that turns amiloplasts into chloroplasts, usually accompanied by the formation of glycoalkaloids, a potentially hazardous substance (Conover \& Prike, 1987). These disorders presented a low incidence and only greening was affected by treatments, difference being observed between Guinea DT and Corn CT (a 42\% higher incidence). The lower incidence of greening is probably related to a greater efficacy in the ridging operation, by providing a higher volume of soil over the tubers, avoiding exposition to the sun. Guinea DT presented the highest biomass production among the treatments, which may have provided a higher efficacy of the ridging operation.

In summary, total potato productivity was higher with deep tillage, regardless the grass species cultivated in succession. The occurrence of superficial common scab was affected by the treatments, the highest and the lowest incidences being obtained in corn and Guinea grass, respectively, both with deep tillage. Soil density, macroporosity and penetration resistance indices were affected by the use of deep tillage and, in a minor degree, by the grass species. These soil properties were significantly better in deep tillage, demonstrating the higher efficacy of this system for the potato crop.

\section{ACKNOWLEDGEMENTS}

To MAFES Inteligência Agronômica and MAFES Agromecânica for the development and manufacture of the machines used in the deep tillage system for potato. To PACES Group Projetando Agricultura Compromissada em Sustentabilidade (www.paces.com. br), which carried out the experiment for seven years, allowing this long-term research. To ESALQ/USP and CAPES for the support.

\section{REFERENCES}

ABREU, SL; REICHERT, JM; REINERT, DJ. 2004. Escarificação mecânica e biológica para a redução da compactação em argissolo franco- 
arenoso sob plantio direto. Revista Brasileira de Ciência do Solo 28: 519-531.

ASSIS, RL; LANÇAS, KP. 2005. Avaliação dos atributos físicos de um Nitossolo Vermelho Distroférrico sob Sistema Plantio Direto, preparo convencional e mata nativa. Revista Brasileira de Ciência do Solo 29: 515-522.

BISHOP, JC; GRIMES, DW. 1978. Precision tillage effects on potato root and tuber production. American Potato Journal 55: 65-71.

BRONICK, CJ; LAL, R. 2005. Soil structure and management: a review. Geoderma 124: 3-22.

CHANTIGNY, MH; ANGERS, DA; BÉLANGER, G; ROCHETTE, P; ERIKSEN-HAMEL, N; BITTMAN, S; BUCKLEY, K; MASSÉ, D; GASSER, M. 2008. Yield and nutrient export of grain corn fertilized with raw and treated liquid swine manure. Agronomy Journal 100: 1303-1309.

CONOVER, JC; PRIKE, JA. 1987. Plastid and nuclear DNA in potato tuber tissue during greening. Journal of Experimental Botany 38: 1219-1227.

DE BOER, SH. 2008. Managing soft rot and ring rot. In: JOHNSON, DA (ed). Potato health management. Saint Paul: The American Phytopathological Society, p.171-182.

EMBRAPA. 1997. Manual de métodos de análises de solo. Brasília: Embrapa, 212p.

IBGE. 2014. Levantamento sistemático da produção agrícola: pesquisa mensal de previsão e acompanhamento das safras agrícolas no ano civil - novembro de 2014. Levantamento Sistemático da Produção Agrícola 27: 1-86.

JADOSKI, SO; SAITO, LR; MAGGI, MF; WAGNER, MV; TAIÃ, NR. 2012. Formas de mecanização e manejo do solo para a cultura da batata I - características da produção.
Engenharia Agrícola 32: 889-899.

RAGASSI, CF. 2009. Sistema de preparo profundo de solo e sucessão de gramíneas para o plantio da batata (Solanum tuberosum L.). Piracicaba: USP-ESALQ. 82p (Dissertação mestrado).

RAGASSI, CF; FAVARIN, JL; MELO, PCT; SHIRAISHI, FA; SAKO, H. 2011. Qualidade do solo e sustentabilidade na cultura da batata. Scientia Agraria Paranaensis 10: 88-103.

RAGASSI, CF; FAVARIN, JL; SHIRAISHI, FA; MOITA, AW; SAKO, H; MELO, PCT. 2009. Efeito da descompactação profunda de solo na produção da cultura da batata. Horticultura Brasileira 27: 484-489. DOI: 10.1590/S010205362009000400014.

RAIJ, B; CANTARELLA, H; QUAGGIO, JA; FURLANI, AMC 1997. Recomendações de adubação e calagem para o Estado de São Paulo. Campinas: Instituto Agronômico/ Fundaçao IAC, 285p.

RIBEIRO, KD; NASCIMENTO, JMS; GOMES, NM; LIMA, LA; MENEZES, SM. 2007. Relações matemáticas entre porosidade drenável e condutividade hidráulica do solo saturado. Revista Brasileira de Engenharia Agrícola e Ambiental 11: 600-606.

SAITO, LR; JADOSKI, SO; MAGGI, MF; SALES, LLSR; SUCHORONCZECK, A. 2013. Formas de mecanização e manejo do solo para a cultura da batata II - desenvolvimento vegetativo. Engenharia Agrícola 33: 993-1002. DOI: 10.1590/S0100-69162013000500011.

SALTON, JC; MIELNICZUK, J; BAYER, C; BOENI, M; CONCEIÇÃO, PC; FABRÍCIO, AC; MACEDO, MCM; BROCH, DL. 2008. Agregação e estabilidade de agregados do solo em sistemas agropecuários em Mato Grosso do Sul. Revista Brasileira de Ciência do Solo 32: 11-21.
SILVA, AP; IMHOFF, S; KAY, B. 2004. Plant response to mechanical resistance and air-filled porosity of soils under conventional and notillage system. Scientia Agricola 61: 451-456. DOI: $10.1590 / \mathrm{S} 0103-90162004000400016$.

SILVA, FAS; AZEVEDO, CAV. 2002. Versão do programa computacional Assistat para o sistema operacional Windows. Revista Brasileira de Produtos Agroindustriais 4: 71-78.

STALHAM, MA; ALLEN, EJ; ROSENFELD, AB; HERRY, FX. 2007. Effects of soil compaction in potato (Solanum tuberosum) crops. Journal of Agricultural Sciences 145: 295-312.

STOLF, R; FERNANDES, J; FURLANI NETO, V. 1983. Penetrômetro de impacto- IAA/ Planalsucar - STOLF (Recomendações para seu uso). STAB - açúcar, álcool e subprodutos 1: $18-23$.

THORNTON, M; STARK, J; HOPKINS, BG; THORNTON, RE. 2008. Selecting and preparing the planting site. In: JOHNSON, DA (ed). Potato health management. Saint Paul: The American Phytopathological Society p.23-30.

VEZZANI, FM; CONCEIÇÃO, PC; MELO, NA; DIECKOW, J. 2008. Matéria orgânica e qualidade do solo. In: SANTOS, GA; SILVA, LS; CANELLAS, LP; CAMARGO, FAO (eds) Fundamentos da matéria orgânica do solo: ecossistemas tropicais e subtropicais. Porto Alegre: Metrópole p. 483-494.

YOUNG, IM; BENGOUGH, AG; MACKENZIE, CJ; DICKSON, JW. 1993. Differences in potato development (Solanum tuberosum cv. Maris Piper) in zero and conventional traffic treatments are related to soil physical conditions and radiation interception. Soil and Tillage Research 26: 341-359. 